OPEN ACCESS

Edited by:

Peng Li,

University of Macau, China

Reviewed by:

JianLi Gao,

Zhejiang Chinese Medical

University, China

Ao Li,

Chongqing University of Technology,

China

*Correspondence: Juan Hu

huj@fitcm.edu.cn

Wen-sheng Pang

pws@fitcm.edu.cn

${ }^{t}$ These authors have contributed equally to this work

Specialty section:

This article was submitted to

Ethnopharmacology,

a section of the journal

Frontiers in Pharmacology

Received: 08 January 2020

Accepted: 22 May 2020

Published: 09 June 2020

Citation:

Lu F, Yang H, Lin S-d, Zhao L, Jiang C,

Chen Z-b, Liu Y-y, Kan Y-j, Hu J and

Pang W-s (2020) Cyclic Peptide

Extracts Derived From Pseudostellaria

heterophylla Ameliorates COPD via

Regulation of the TLR4MyD88

Pathway Proteins.

Front. Pharmacol. 11:850.

doi: 10.3389/fphar.2020.00850

\section{Cyclic Peptide Extracts Derived From Pseudostellaria heterophylla Ameliorates COPD via Regulation of the TLR4/MyD88 Pathway Proteins}

\author{
Feng Lu ${ }^{1,2 \dagger}$, Han Yang ${ }^{1 \dagger}$, Si-ding Lin ${ }^{1}$, Li Zhao ${ }^{3}$, Chang Jiang ${ }^{3}$, Zhi-bin Chen ${ }^{2}$, \\ Ying-ying Liu ${ }^{2}$, Yong-jun Kan ${ }^{3}$, Juan $\mathrm{Hu}^{1,2^{*}}$ and Wen-sheng Pang ${ }^{1 *}$ \\ ${ }^{1}$ School of Pharmacy, Fujian University of Traditional Chinese Medicine, Fuzhou, China, ${ }^{2}$ Respiratory Department, The \\ Second Affiliated Hospital of Fujian Traditional Chinese Medical University, Fuzhou, China, ${ }^{3}$ Institute of Materia Medica, Fujian \\ Academy of Traditional Chinese Medicine, Fuzhou, China
}

We have explored the method of extraction and purification of cyclic-peptide extract (CPE) from Pseudostellaria heterophylla (Miq.) Pax. (Taizishen, TZS), characterized the structure about cyclic-peptide compounds and investigated the biological activity of CPE attenuating chronic obstructive pulmonary disease (COPD) in rats. The CPE from TZS was obtained by ethyl acetate, petroleum ether, hot water extraction, and alcohol-precipitation. Cyclicpeptide structures were distinguished using ultra-high performance liquid chromatographyquadrupole time-of-flight tandem mass spectrometry (UPLC-Q-TOF-MS/MS). Rats were induced by solid combustibles smoke (SCS) for the COPD model, and the anti-COPD activity of CPE was detected using lung airway resistance and dynamic lung compliance, as well as pulmonary tissue hematoxylin and eosin (HE) staining. The relevant inflammatory cytokines were assayed by enzyme-linked immunosorbent assay (ELISA). CPE obtained from TZS contained 12 cyclic-peptide constituents; the purity was up to $92.94 \%$. CPE (200, 400 , or $500 \mathrm{mg} / \mathrm{kg} /$ day) was given to SCS-induced COPD model rats orally for 15 days. The results showed that in rats given CPE $(400 \mathrm{mg} / \mathrm{kg} /$ day) there was a sharp fall in lung airway resistance but a rise in dynamic lung compliance. The image analysis of lung tissue sections suggested that CPE could decrease the degree of alveolar destruction $(p<0.05)$, alleviate lung inflammation, increase alveolar space, and improve the infiltration of inflammatory cells. CPE was found to reduce the levels of TNF- $\alpha$, but increase IL-10, adjusting multiple cytokines in rat serum; the TLR4 mRNA, MyD88 mRNA and AP-1 mRNA levels, the expressing levels of p-JNK, p-p38 and p-TAK1 protein were significantly down regulated in rat alveolar macrophages. CPE intervention could improve the pulmonary ventilation function on COPD rats, which may be related to its effect in inhibiting the abnormal activation of the TLR4-MyD88-JNK/p38 pathway. This is the first report that the CPE of TZS lessens the severity of COPD episodes. The new preparation process of CPEs implements the anticipated goal, which is to refine CPE and actualize quality control.

Keywords: Pseudostellaria heterophylla, cyclic peptide, monomer structure, TLR4-MyD88-JNK/p38 pathway, antichronic obstructive pulmonary disease 


\section{INTRODUCTION}

Chronic obstructive pulmonary disease (COPD) is a noteworthy public health problem due to its morbidity and mortality (Lindberg et al., 2012). COPD exhibits symptoms of airflow blockage and breathlessness and includes emphysema, chronic bronchitis, or even asthma. Diagnosis of COPD can be best addressed by a combination of morphology and function. The morphological imaging of the lung parenchyma and airways can be detected using the three-dimensional high-resolution computed tomography (CT) technique. The image information obtained by functional imaging is perfusion, lung mechanics, and ventilation by magnetic resonance imaging (MRI). The comprehensive diagnostics of CT complemented with MRI are able to achieve a more sensitive detection (Ley et al., 2008). The development of COPD is mainly attributable to smoking, but genetic factors and respiratory infections are some of the most common causes of asthma; air pollution can aggravate asthma. In developing countries, air quality is thought to have a larger role in the progression of COPD (David and Victor, 2006).

COPD is closely correlated with a chronic inflammatory response, which is characterized by an increased amount of macrophages, neutrophils, and $\mathrm{T}$ lymphocytes in the small airways and lung parenchyma (Pelaia et al., 2006). In contrast to asthma, the inflammatory mediators involved in COPD are not clear, but inflammation comprises many mediators, factors, and pathways such as inflammatory peptides, lipid mediators, active oxygen, and cytokines that cause alveolar destruction and small airway fibrosis. Recognizing the inflammatory factors and understanding the interaction mechanism is crucial for antiinflammatory treatments of COPD (Barnes et al., 2004).

COPD is a non-specific inflammatory disease, and an abnormal immune response plays an important role. Toll-like receptors (TLRs) have been studied that are a cornerstone of the innate immune system and play a pluripotent role in stable COPD. Myeloid differentiation primary response protein 88 (MyD88) is a critical adaptor protein involved in the TLR family signaling pathway and regulates immune responses and inflammation. Targeting MyD88 is one way to treat COPD (Di Stefano et al., 2017; Franco et al., 2018).

Coughing and wheezing can be treated with drugs. Patients who have low blood oxygen concentrations are often given supplemental oxygen. Even though the overall prognosis of COPD patients has shown some improvement, the mortality rate remains high (Bruno and Valenti, 2012).

China has a long history of traditional medicines; the treatment of lung disease focuses the lung deficiency syndrome on purging the lung and dissolving phlegm. Many Chinese herbals have been used for several thousand years to treat respiratory diseases such as cough, asthma, bronchial ailments, and pneumonia (Jiangsu New Medical College, 1977; Lin, 2004; Wang and Ng, 2006; Zhou, 2005; Hsu et al., 2013).

In traditional Chinese medicine (TCM), Pseudostellaria heterophylla (TZS) can moisten the lung, cough, and is a spleen tonic. TZS is a mild herb that strengthens the Qi to tone up the body and resist pulmonary diseases (Yan, 2008). Some studies indicate that TZS possesses immunologic enhancement and antioxidant properties (Wong et al., 1994; Ng et al., 2004; Zhou, 2005; Huang et al., 2005). The ethyl acetate extract of TZS relieves cough and improves lung function via adjustment of the levels of multiple cytokines (Pang et al., 2011). The ethyl acetate extract of TZS contains cyclic-peptide compounds; the activity of these cyclic-peptide fractions is not clear.

In this paper, according to the clinical use of this herb in TCM (Murărescu et al., 2008), the present study was undertaken to evaluate cyclic-peptides separated from the ethyl acetate extract of TZS attenuating a COPD rat model induced by solid combustibles smoke (SCS), and also characterize the structures of the cyclic peptide monomer. Enzyme-linked immunosorbent assay (ELISA) was used to detect tumor necrosis factor (TNF- $\alpha$ ) and interleukin-10 (IL-10), quantitative real-time polymerase chain reaction (q-PCR) and western blotting (WB) were used to detect the TLR4 mRNA, MyD88 mRNA and AP-1 (activator protein-1) mRNA meanwhile the downstream protein expression of p-p38 (phosphorylated protein 38), p-JNK (phosphorylated c-jun amino terminal kinase), IKK (inhibitor of nuclear factor $\mathrm{\kappa B}$ kinas), $\mathrm{p}$-І $\mathrm{KB}$ (phosphorylated inhibitor of NF- $\mathrm{KB}$ ), and TAK1 (transforming growth factor beta-activated kinase 1) of the TLR4 pathway, regulated by CPE, to clarify its mechanism of action. Some particular molecules of cyclicpeptides are naturally present in P. heterophylla but their activity was seldom reported. It is of profound interest to elucidate this substance class.

\section{MATERIALS AND METHODS}

\section{Chinese TZS and Chemicals}

Zheshen No. 2 P. Heterophylla (Miq.) Pax Chinese herbal was purchased from Ningde Nanling Agricultural Co., Ltd. Zherong County of the Ningde region of the Fujian Province in China is the advocate producing area of TZS. The TZS was cut into pieces and then dried below $60^{\circ} \mathrm{C}$.

Chromatographic pure methanol was purchased from Merck KGaA (Darmstadt, Germany). Chromatographic pure acetonitrile was purchased from Fisher Scientific UK Ltd. (Leicestershire, England). Analytical grade reagents including petroleum ether, ethyl acetate, ethanol, n-butanol, ammonia, and chloroform were bought from Xilong Scientific Co., Ltd. (Shantou, China). Interleukin-10 (IL-10) and tumor necrosis factor (TNF- $\alpha$ ) enzyme linked immunosorbent assay (ELISA) kits were purchased from cloud-clone corp.

\section{Instruments}

A high performance liquid chromatography (HPLC) system with a 2996 photodiode-array detector (PDA) and an auto-sampler was used (Waters Technologies, USA). Liquid chromatography tandem mass spectrometry (LC-MS/MS) was performed with an Agilent 1290 ultra-high performance liquid chromatography (UPLC) combined with an AB Sciex Triple time of flight (TOF) 4600 MS system. A SpectraMax Plus384 multimode micro-plate reader (Molecular Devices, USA) and a Milli-Q-Plus ultra-pure water system (Millipore, Bedford, MA, USA) were used. 


\section{CPE Preparation and Purification}

The TZS was crushed to a powder (through 60 meshes) and was extracted using ethyl acetate as the solvent. According to the properties of the substance, the crude extract was purified by selecting the appropriate solvent to obtain the refined CPE.

Previous research of our group found that the ethyl acetate extract of TZS is rich in amino acids, cyclic peptides, and free fatty acids. Using several solvents to remove impurities, the process of CPE purification consisted of three steps: the ethyl acetate extract of TZS was degreased with petroleum ether, amino acids were removed with hot water, and polysaccharide and other impurities were removed with alcohol-precipitation. The purified cyclic-peptide powder was freeze-dried by lyophilization (Figure 1).

\section{Ethyl Acetate Crude Extracts Preparation and HPLC-Fingerprint Analysis}

TZS (60 mesh) was extracted with ethyl acetate using the Soxhlet extraction method for $2 \mathrm{~h}$ at $90^{\circ} \mathrm{C}$. The extract was restored at room temperature, evaporated to dryness, and the ethyl acetate was removed in a rotary evaporator under reduced pressure. The residue was dissolved with chromatographic grade methanol, filtered through a $0.45 \mu \mathrm{m}$ filter before analysis by HPLC. HPLC fingerprint analysis showed that the ethyl acetate extract contained three kinds of substances: amino acids, cyclic peptides, as well as free fatty acids. Thus, if pure cyclic peptides were to be obtained, the ethyl acetate extract needed to be further purified.

\section{Removal of Fat-Soluble Substances}

The ethyl acetate extract was degreased by mixing with petroleum ether (material: liquid $=1: 30$ ) to extract fat-soluble substances using ultrasonic extraction for $1 \mathrm{~h}$ at room temperature. The extract was filtered and the petroleum ether was discarded; the residue was degreased with petroleum ether in triplicate. The solvent was evaporated from the residue and ethanol was added (material: liquid $=1: 30$ ) for ultrasonic extraction at $60^{\circ} \mathrm{C}$ for $1 \mathrm{~h}$. The extract was filtered, restored at room temperature, evaporated to dryness and alcohol was removed in a rotary evaporator under reduced pressure.

\section{Removal of Amino Acids}

The above-mentioned residue was fully dissolved in $50 \mathrm{ml}$ hot water and extracted with ethyl acetate thrice (volume ratio 1:2)

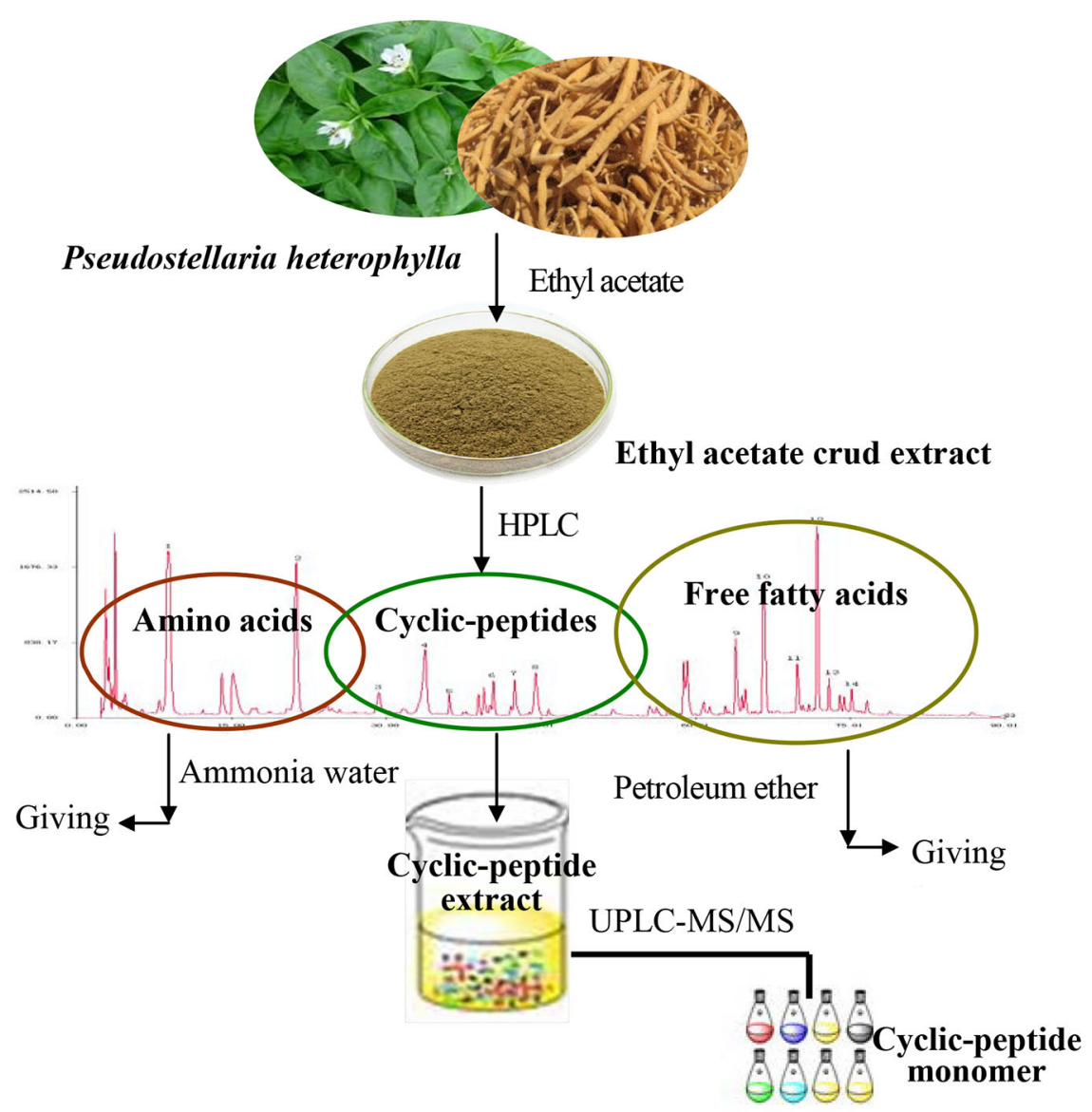

FIGURE 1 | Diagrammatic sketch of cyclic-peptide extract preparation and purification. 
with a separating funnel; $100 \mathrm{ml}$ of ethyl acetate was added each time. After the ethyl acetate phase was concentrated and dried, $50 \mathrm{ml}$ hot water was added to the funnel to dissolve the residue, and $50 \mathrm{ml}$ water-saturated $\mathrm{n}$-butanol was added (volume ratio 1:1) and extracted thrice. The combined n-butanol extraction solution was poured into a separating funnel, $150 \mathrm{ml} 40 \%$ ammonia test solution (volume ratio $1: 1$ ) was added to the nbutanol extraction, and the mixture was agitated well, and extracted thrice. The ammonia test solution extracts were discarded and the n-butanol phase was concentrated and dried. The residue was fully dissolved in $25 \mathrm{ml}$ hot water, $50 \mathrm{ml}$ chloroform was added (volume ratio 1:1) and extracted thrice. The chloroform phase was removed under reduced pressure, and the extract was concentrated and dried.

\section{Removal of Polysaccharide and Other Impurities}

The alcohol precipitation method was used to remove polysaccharides and other impurities. The above residue was placed in a beaker, dissolved with a proper amount of $85 \%$ ethanol, set for a period, filtered, and the resulting filtrate was a clear alcohol solution.

The above alcohol solution was placed in a beaker and mixed with distilled water (volume ratio $1: 1$ ) to obtain a $50 \%$ alcohol solution (freezing point $-25^{\circ} \mathrm{C}$ ). After pre-freezing at $-80^{\circ} \mathrm{C}$, a yellow powder was obtained by freeze-drying in a vacuum freeze-dryer.

\section{Chemical Analysis of the Freeze-Dried Powder}

A little powder was dissolved in methanol and filtered with a 0.22 $\mu \mathrm{m}$ microporous membrane. This paper deals with optimization of the chromatographic fingerprint of CPE to carry out HPLC analysis. The characteristic vibration cyclic-peptide bands showed the best responses at a wavelength of $203 \mathrm{~nm}$, so 203 $\mathrm{nm}$ was successfully used to detect the target components. At the retention time of 25-60 min, 40 compounds with a peak area above $0.01 \%$ showed a better absorbance. For 16 of the 40 components, sixteen peaks were labeled with an area more than three ten thousand and the 40 components accounted for 96.9\% of the total area (Figure 2).

\section{HPLC-Fingerprint Analysis of Extracts}

The chromatography was carried out with a Hypersil ODS column $(4.6 \mathrm{~mm} \times 250 \mathrm{~mm}, 5 \mu \mathrm{m})$ made by Dalian Elite Analytical Instruments Co., Ltd. (Dalian, China). The mobile phase, flow rate and column temperature were optimized to obtain better resolution and establish an HPLC method to determine the fingerprint of the CPE. The mobile phase was acetonitrile (A) and $0.2 \%$ orthophosphoric acid aqueous solution (B).

The gradient elution program included five steps: From 0 to $40 \mathrm{~min}$, the ratio of acetonitrile was increased from 10 to $40 \%$; from 40 to $60 \mathrm{~min}$, the ratio of acetonitrile was increased from 40 to $70 \%$; from 60 to $75 \mathrm{~min}$, the ratio of acetonitrile was increased from 70 to $100 \%$; from 75 to $90 \mathrm{~min}$, the acetonitrile was maintained at $100 \%$. The detection wavelength was set at 203 $\mathrm{nm}$; the flow rate was $1.0 \mathrm{ml} / \mathrm{min}$, sample size was $20 \mu \mathrm{l}$, and the column temperature was $30^{\circ} \mathrm{C}$.

\section{Cyclic-Peptide Ingredient Structure by LC-MS/MS Identification}

UPLC-MS/MS determination was achieved on a SB $\mathrm{C}_{18}(2.1 \times$ $100 \mathrm{~mm}, 1.8 \mu \mathrm{m})$ column. The velocity was $0.4 \mathrm{ml} / \mathrm{min}$. The temperature of the auto-sampler and column were both maintained at $30^{\circ} \mathrm{C}$. Both positive and negative electrospray ionization (ESI) modes were applied. The different instrument parameters including ion source temperature, collision energy, and collision energy spread were designed and optimized for high-quality fragment ions of the mass spectra (Table 1).

\section{COPD Rat Model Preparation and Treatment}

SPF grade Wistar adult rats, male and female (50:50) weighing $200 \pm 25$ g were purchased from Shanghai Laboratory Animals Center (Shanghai, China) and fed in the animal center of our institution. The ambient temperature was $25^{\circ} \mathrm{C}$ and humidity $70 \%$. Rats were allowed free access to tap water and were given a rodent diet.

Some 60 Wistar rats were randomly divided into six groups. The rats were exposed to the admixture of $40 \mathrm{~g}$ of cigarette and

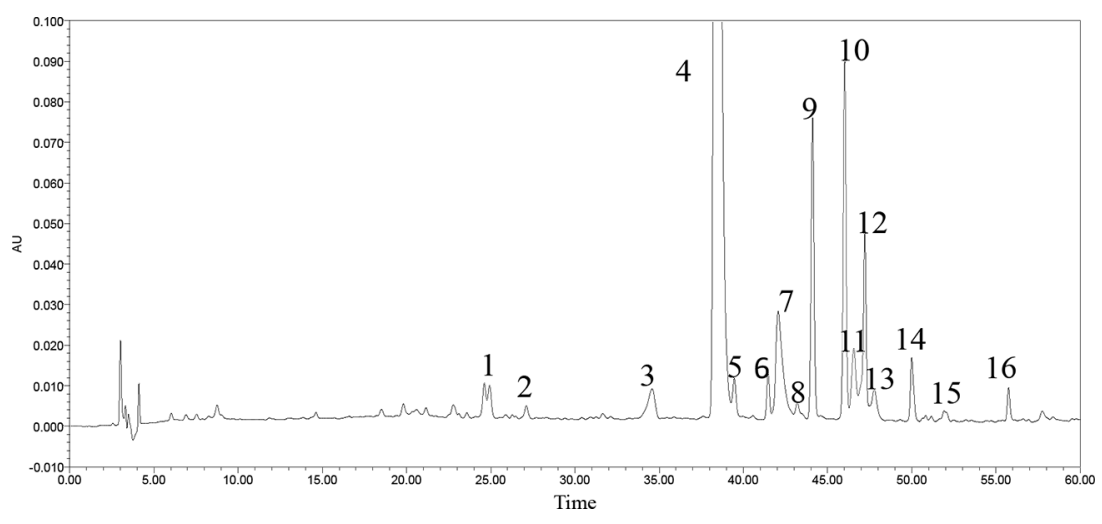

FIGURE 2 | HPLC-fingerprint of cyclic-peptide extract. 
TABLE 1 | CPE UPLC-MS/MS analysis conditions.

Chromatographic conditions

Chromatographic column

Flow rate

Detective wavelength

Sample size

Column temperature

Mobile phase

Gradient program
SB C18 $(2.1 \times 100 \mathrm{~mm}, 1.8 \mu \mathrm{m})$

$0.4 \mathrm{ml} / \mathrm{min}$

$203 \mathrm{~nm}$

$1 \mu \mathrm{l}$

$30^{\circ} \mathrm{C}$

$0.1 \%$ glacial acetic acid aqueous solution $(A)$ - acetonitrile $(B)$

0-11-12-17-19-20-23 min, 10-50-70-100-

$100-10-10 \mathrm{~B} \%$

Mass spectrometry conditions

Polarity

TOF mass range

Ion Source

Ion Source Temp

Ion Spray Voltage Floating

Collision Energy (CE)

Collision Energy Spread (CES)
Positive/Negative ion mode

Min 100, Max 1,500

Gas 50, Curtain Gas 35

$500^{\circ} \mathrm{C}$

$5,020 /-4,500$

$\pm 40$

20
$300 \mathrm{~g}$ of wood chips. The exposure was performed in a $1 \mathrm{~m}^{3}$ fume cupboard with a flow rate of $0.1 \mathrm{~m}^{3} / \mathrm{h}$ and $60 \mathrm{~min}$ daily, for 60 days. Attention was paid to control the velocity of the flow of smoke, to properly ventilate, and to avoid accidental death of the animals. The control groups, consisting of 10 rats were unexposed to pollutants. Physiological saline was used as solvent to prepare suspension of CPE. Rats were orally given CPE at the low dose of $200 \mathrm{mg} / \mathrm{kg}$ (CPE-LD), medium dose of $400 \mathrm{mg} / \mathrm{kg}$ (CPE-MD), and high dose of $500 \mathrm{mg} / \mathrm{kg}$ (CPE-HD) for 15 days.

Guilong Kechuanning capsule is a classical proprietary Chinese medicine (license number Z20053135). Guilong Kechuanning capsule is effective for lung diseases such as COPD and acute or chronic bronchitis, and for the improvement of immunological function and cellular cytokines such as IL- 8 and TNF- $\alpha$ in patient with COPD (Huang and Cai, 1993; Li et al., 2005). In this study, rats were orally given physiological saline suspension of Guilong Kechuanning capsule $(450 \mathrm{mg} / \mathrm{kg} /$ day) for 15 days that as a positive control.

The vehicle control and model control groups were given an equal amount of physiological saline by gastric perfusion, respectively.

\section{Pulmonary Function Assessment}

Changes in the lung function of rats were observed using MedLab after treatment with CPE. Rats were anesthetized with pentobarbital sodium at a dose of $30 \mathrm{mg} / \mathrm{kg}$ and placed in a plethysmograph. Airway flow $(\mathrm{V})$, tidal volume $\left(\mathrm{V}_{\mathrm{t}}\right)$, and transpulmonary pressure (Ptp) were monitored for $30 \mathrm{~min}$ and changes in each parameter were recorded. The effect of CPE was determined by comparing the COPD model changes in lung airway resistance $\left(\mathrm{R}_{\mathrm{L}}\right)$ and dynamic compliance (Cdyn) (Pang et al., 2011).

\section{Image Analysis of Lung Tissue Sections}

Pulmonary tissue sections were made for pathological examination. A certain thickness of pulmonary tissue was made of random sections according to Valença et al. (Weibel and Gomez, 1962; Valença et al., 2004). Lung tissue sections were stained with hematoxylin and eosin (HE) and were studied morphologically under the light microscope. Dilated alveolar spaces and alveolar morphological characteristics were counted and identified using the $100 \times$ field of view for each group.

\section{Rat Serum Preparation, Alveolar Macrophage (AM) Isolation and Identification}

When the CPE treatment was concluded, rats were given $1 \%$ pentobarbital sodium as an anesthetic. About $5 \mathrm{ml}$ of blood was collected from inferior vena cava and was centrifuged for $20 \mathrm{~min}$ at $3,000 \mathrm{r} / \mathrm{min}$ to prepare serum was stored at $-80^{\circ} \mathrm{C}$ for ELISA detection. The trachea and lungs were exposed and pulmonary alveolar macrophages (AMs) from each group were separated by bronchoalveolar lavage fluid (BALF) extraction. Briefly, a $2 \mathrm{~mm}$ diameter tube was inserted into the bronchus and $5 \mathrm{ml}$ sterile saline was pumped in and then removed along with the fluid and cells; this was repeated four times. To amalgamate BALFs, the fluid was centrifuged for $15 \mathrm{~min}$ at 1,000 $\mathrm{r} / \mathrm{min}$. Cell precipitates were used to prepare single cell suspension by a floating and sinking process with RPMI-1640 medium containing 10\% FBS, $100 \mathrm{U} / \mathrm{ml}$ penicillin, and $100 \mathrm{U} / \mathrm{ml}$ streptomycin. Giemsa stain was used to confirm AM purity $>90 \%$ and trypan blue staining identified a cell survival rate $\geq 95 \%$. AMs were inoculated in a culture dish at a concentration of $1 \times 10^{9} / \mathrm{ml}$ under an atmosphere of $37^{\circ} \mathrm{C}, 5 \% \mathrm{CO}_{2}$ for $2 \mathrm{~h}$ to gain the adherent cells. AMs were stored in liquid nitrogen for PCR and WB detection (Huang et al., 2015; Yu et al., 2018).

\section{Cytokine Measurement by ELISA}

The levels of TNF- $\alpha$ and IL-10 in serum and the supernatant of AMs were detected by ELISA kits, respectively. The operation manual was read carefully before testing.

\section{Q-PCR Assay}

RNA extraction of AMs was performed using a RNA Fast Mini kit (GK3016, Generay, Shanghai, China). According to the manufacturer's instructions, RNA was extracted and stored at $-80^{\circ} \mathrm{C}$. Reverse transcription was performed using the HiScriptII Q RT SuperMix for qPCR (Vazyme, Nanjing, China). A CFX connect Real-Time PCR System (Bio-Rad Laboratories, USA) was used to assay the gene expression of TLR4, MyD88, and AP1 in AMs.

The PCR primers for TLR4, MyD88 and the internal reference, GAPDH, were designed based on DNA gene sequences from the GenBank website. The three pairs of primers were:

TLR4: F 5'- GACACTTTATCCAGAGCCGTTG -3', R 5'- GGACTTCTCCACTTTCTCAAGG -3' 
MyD88: F 5' - CAACCAGCAGAAACAGGAGTCT -3', R 5' - ATTGGGGCAGTAGCAGATGAAG -3'

AP-1: 5' -AAACGACCTTCTACGACGATG-3',

5'-TCGGAGGTGCGGCTTCAGATT-3'

GAPDH: F 5' - TATGACTCTACCCACGGCAAGT -3', R 5' - ATACTCAGCACCAGCATCACC -3'

The PCR amplification reaction contained $10 \mu \mathrm{l} 2 \times$ ChamQ SYBR Color qPCR Master Mix, $0.6 \mu \mathrm{l} 10 \mu \mathrm{M}$ forward primer, 0.6 $\mu \mathrm{l} 10 \mu \mathrm{M}$ reverse primer, $2 \mu \mathrm{l}$ template cDNA, and distilled water $\left(\mathrm{dH}_{2} \mathrm{O}\right)$ was added to $20 \mu \mathrm{l}$. PCR was conducted with the following reaction conditions: $95^{\circ} \mathrm{C}$ for $30 \mathrm{~s}$, and 40 cycles of $95^{\circ} \mathrm{C}$ for $10 \mathrm{~s}, 59^{\circ} \mathrm{C}$ for $30 \mathrm{~s}$, and $60^{\circ} \mathrm{C}$ for $30 \mathrm{~s}$. A melting curve was performed from 70 to $95^{\circ} \mathrm{C}$ in increments of $0.5^{\circ} \mathrm{C}$ for $5 \mathrm{~s}$.

\section{Western Blotting Analysis}

The cells were harvested after treatment for 12,24 , and $48 \mathrm{~h}$. AM lysate protein was extracted and analyzed by $12 \%$ sodium dodecyl sulfate polyacrylamide gel electrophoresis (SDS-PAGE) that was transferred to a polyvinylidene difluoride (PVDF) membrane, and then blocked for $1 \mathrm{~h}$ with $5 \%$ non-fat milk. The membrane was incubated overnight with the following primary antibodies: JNK, p38, IKK, IKB, TAK1, and AP-1 $(1: 1,000)$, and GAPDH $(1: 5,000)$. Membranes were immersed in $1 \times$ TBST buffer, washed on a shaker three times for $10 \mathrm{~min}$, incubated with secondary antibodies $(1: 10,000)$ for $1 \mathrm{~h}$, and the membranes were washed with TBST. The bands were quantified by image software.

\section{RESULTS}

\section{Freeze-Dried Powder Identification by UPLC-MS/MS Analysis}

Both positive and negative ESI modes were applied, and the positive ESI response was much better than the negative ESI response. $\mathrm{ESI}^{+}$mode, (positive ions) such as $[\mathrm{M}+\mathrm{H}]^{+}$and $[\mathrm{M}+$ $\left.\mathrm{NH}_{4}\right]^{+}$, were measured in mass in a full scan. Molecular and characteristic fragment ions of 16 chemical components are seen in Table 2. Their structures were investigated through

TABLE 2 | Peak area information of freeze-dried powder methanol solution.

\begin{tabular}{|c|c|c|c|c|c|c|c|c|c|c|c|}
\hline \multicolumn{6}{|c|}{ HPLC-fingerprint analysis } & \multicolumn{6}{|c|}{ UPLC-MS/MS analysis } \\
\hline $\begin{array}{l}\text { Marking } \\
\text { peak no. }\end{array}$ & $\begin{array}{c}\mathrm{RT} \\
\text { (min) }\end{array}$ & $\begin{array}{l}\text { Peak } \\
\text { area } \\
(\mu \mathrm{A} \mu)\end{array}$ & $\begin{array}{c}\text { Peak area } \\
\text { percentage } \\
(\%)\end{array}$ & $\begin{array}{c}\text { CP peak } \\
\text { area } \\
\text { percentage } \\
(\%)\end{array}$ & $\begin{array}{c}\mathrm{RT} \\
(\mathrm{min})\end{array}$ & $\begin{array}{c}m / z \\
(M+H)\end{array}$ & $\begin{array}{l}\text { Mass } \\
\text { Error } \\
\text { (ppm) }\end{array}$ & Fomula & MW. & Name & MS/MS \\
\hline 1 & 24.62 & 116,498 & 0.77 & - & 4.40 & $\begin{array}{r}432.2817 \\
(\mathrm{M}+\mathrm{NH} 4)\end{array}$ & -5.9 & $\mathrm{C}_{19} \mathrm{H}_{34} \mathrm{~N}_{4} \mathrm{O}_{6}$ & 414.25 & Leu Pro Val Ser & $\begin{array}{c}265.1616 ; 177.1112 \\
133.0851 ; 89.0588\end{array}$ \\
\hline 2 & 27.12 & 48,684 & 0.32 & 0.32 & 6.72 & 488.2504 & -0.5 & $\mathrm{C}_{24} \mathrm{H}_{33} \mathrm{~N}_{5} \mathrm{O}_{6}$ & 487.24 & Heterophyllin J & $\begin{array}{c}460.2562 ; 297.1904 \\
169.1322 ; 70.0646\end{array}$ \\
\hline 3 & 34.58 & 220,233 & 1.45 & 1.45 & 7.48 & 502.2660 & -1 & $\mathrm{C}_{25} \mathrm{H}_{35} \mathrm{~N}_{5} \mathrm{O}_{6}$ & 501.26 & Pseudostellarin A & $\begin{array}{c}474.2715 ; 361.1877 \\
233.1282,70.0652\end{array}$ \\
\hline 4 & 38.39 & $9,829,954$ & 64.56 & 64.56 & 7.62 & 564.2817 & -0.8 & $\mathrm{C}_{30} \mathrm{H}_{37} \mathrm{~N}_{5} \mathrm{O}_{6}$ & 563.27 & $\begin{array}{l}\text { new } \\
\text { pseudostellarin }\end{array}$ & $\begin{array}{c}536.2865 ; 318.1449 \\
155.0812,70.0650\end{array}$ \\
\hline 5 & 39.46 & 141,146 & 0.93 & 0.93 & 8.62 & 683.3511 & -0.2 & $\mathrm{C}_{33} \mathrm{H}_{46} \mathrm{~N}_{8} \mathrm{O}_{8}$ & 682.34 & Pseudostellarin B & $\begin{array}{c}665.3406 ; 570.2670 \\
212.1389\end{array}$ \\
\hline 6 & 41.47 & 131,686 & 0.86 & 0.86 & 8.83 & 785.4192 & -2.4 & $\mathrm{C}_{38} \mathrm{H}_{56} \mathrm{~N}_{8} \mathrm{O}_{10}$ & 784.41 & Pseudostellarin F & $\begin{array}{c}757.4240 ; 672.3340 \\
308.1957\end{array}$ \\
\hline 7 & 42.07 & 741,190 & 4.87 & 4.87 & 9.45 & 779.445 & -2.1 & $\mathrm{C}_{40} \mathrm{H}_{58} \mathrm{~N}_{8} \mathrm{O}_{8}$ & 778.44 & Heterophyllin B & $751.4508 ; 405.2494$ \\
\hline 8 & 43.20 & 37,451 & 0.25 & 0.25 & 10.02 & 813.4505 & 1.5 & $\mathrm{C}_{40} \mathrm{H}_{60} \mathrm{~N}_{8} \mathrm{O}_{10}$ & 812.44 & Pseudostellarin C & $\begin{array}{c}795.4441 ; 471.2972 \\
358.2137\end{array}$ \\
\hline 9 & 44.11 & 912,328 & 5.99 & 5.99 & 10.09 & 714.4185 & 1 & $\mathrm{C}_{36} \mathrm{H}_{55} \mathrm{~N}_{7} \mathrm{O}_{8}$ & 713.41 & Pseudostellarin D & $\begin{array}{l}686.4253 ; 601.3354 \\
573.3397 ; 211.1442\end{array}$ \\
\hline 10 & 46.01 & $1,049,294$ & 6.89 & 6.89 & 10.61 & 728.4341 & 0.6 & $\mathrm{C}_{37} \mathrm{H}_{57} \mathrm{~N}_{7} \mathrm{O}_{8}$ & 727.43 & Heterophyllin A & $\begin{array}{l}710.4245 ; 615.2519 \\
310.2149 ; 197.1280\end{array}$ \\
\hline 11 & 46.56 & 340,299 & 2.24 & - & 10.67 & 498.2459 & -2.7 & $\mathrm{C}_{24} \mathrm{H}_{31} \mathrm{~N}_{7} \mathrm{O}_{5}$ & 497.24 & His Gly Trp Val & $212.1178 ; 110.0709$ \\
\hline 12 & 47.21 & 649,931 & 4.27 & 4.27 & 11.00 & 817.4243 & -0.2 & $\mathrm{C}_{42} \mathrm{H}_{56} \mathrm{~N}_{8} \mathrm{O}_{9}$ & 816.42 & Pseudostellarin G & $\begin{array}{l}\text { 799.4176; 555.2935; } \\
467.2297 ; 332.1605\end{array}$ \\
\hline 13 & 47.77 & 176,064 & 1.16 & 1.16 & 11.30 & 878.5135 & 0.6 & $\mathrm{C}_{45} \mathrm{H}_{67} \mathrm{~N}_{9} \mathrm{O}_{9}$ & 877.51 & Pseudostellarin $\mathrm{E}$ & $\begin{array}{l}\text { 765.4313; 674.4264; } \\
\text { 365.2195; 308.1971 }\end{array}$ \\
\hline 14 & 49.99 & 211,700 & 1.39 & 1.39 & 12.10 & 665.3657 & 0.3 & $\mathrm{C}_{35} \mathrm{H}_{48} \mathrm{~N}_{6} \mathrm{O}_{7}$ & 664.36 & Heterophyllin D & $\begin{array}{c}647.3575 ; 387.2019 \\
288.1325\end{array}$ \\
\hline 15 & 51.92 & 57,081 & 0.37 & - & 16.13 & 279.2319 & -0.2 & $\mathrm{C}_{18} \mathrm{H}_{30} \mathrm{O}_{2}$ & 278.22 & $\begin{array}{l}\text { Octadecatrinoic } \\
\text { acid }\end{array}$ & $\begin{array}{c}\text { 149.0231; } 95.0852 ; \\
81.0700 ; 67.0546\end{array}$ \\
\hline 16 & 55.75 & 88,005 & 0.58 & - & 19.93 & $\begin{array}{c}277.2173 \\
(\mathrm{M}-\mathrm{H})\end{array}$ & 0.3 & $\mathrm{C}_{18} \mathrm{H}_{30} \mathrm{O}_{2}$ & 278.42 & Linolenic acid & $\mathrm{N} / \mathrm{A}$ \\
\hline Area & & & 96.9 & 92.94 & & & & & & & \\
\hline
\end{tabular}


fragmentation reactions of mass spectrum and compared with the existing literature (Fu et al., 2012; Hua et al., 2017). [M+ H] $]^{+}$ at $\mathrm{m} / z$ 432.2817 (M + NH4), $\mathrm{m} / z$ 488.2504, $\mathrm{m} / z$ 502.266, $\mathrm{m} / \mathrm{z}$ $564.2817, \mathrm{~m} / z$ 683.3511, $\mathrm{m} / \mathrm{z} 785.4192, \mathrm{~m} / z$ 779.445, $\mathrm{m} / \mathrm{z}$ $813.4505, m / z 714.4185 \mathrm{~m} / z$ 728.4341, $\mathrm{m} / z$ 498.2459, $\mathrm{m} / z$ 817.4243, $\mathrm{m} / z$ 878.5135, $\mathrm{m} / z$ 665.3657, $\mathrm{m} / \mathrm{z} 279.2319, \mathrm{~m} / \mathrm{z}$ 277.2173(M-H), respectively. Peaks $1-16$ was identified as LeuPro-Val-Ser molecules, Heterophyllin J, Pseudostellarin A, new Pseudostellarin, Pseudostellarin B, Pseudostellarin F, Heterophyllin B, Pseudostellarin C, Pseudostellarin D, Heterophyllin A, His-Gly-Trp-Val molecules, Pseudostellarin G, Pseudostellarin E, Heterophyllin D, octadecatrinoic acid, and linolenic acid/ $\alpha$-linolenic acid, respectively. There were 12 cyclic peptide monomer components of the 16 compounds; peak 4 was tentatively identified as one cyclic peptide compound and its structure must be further confirmed. The structures of 11 cyclic peptide monomers are shown in Figure 3. The relative contents in percentage were calculated using the area normalization method, after the ethyl acetate crude extract was purified to remove naturally occurring impurities, which indicated that the cyclic-peptides content in freeze-dried powder was up to $92.94 \%$. Freeze-dried powder was the refined $\mathrm{CPE}$.

\section{TZS Cyclic Peptide Anti-COPD Activity The Safety Preliminarily Evaluating by Feeding Rats With CPE for 28 Days}

According to the State Food and Drug Administration (SFDA) "Technical guidelines for repeated drug administration toxicity testing", we tested the toxicity through twenty-eight days feeding study. A total of $100 \mathrm{SPF}$ grade Wistar weaning rats, weighted $(80 \pm 10) \mathrm{g}$ were divided randomly into five groups, 10 male rats and 10 female rats in each group, namely blank control group, vehicle control group, 200, 400 and $500 \mathrm{mg} / \mathrm{kg} / \mathrm{d}$ dose of CPE group. Rats were fed the corresponding dose of drug or vehicle. On the 30th day, samples of blood were collected for hematological and biochemical analysis. Livers, spleens, kidneys and testicles (ovariesy) from all rats were weighed, furthermore, and the ratio of these organs to body weight was determined. The liver, kidneys, spleen, stomach, duodenum, testicles, ovariesy were removed for histopathological examinations. The tested animals were generally in good condition that both experimental groups and control group grown healthy and there was no abnormal change in body weight. Pathological examination of the experimental groups was negative. The results of hematological and biochemical indexes showed that all the indexes were in the normal range, the recommended dose of CPE was given to animals, and no toxicity was observed, results were listed Tables $\mathbf{3 A}, \mathbf{B}$.

\section{CPE Improves Pulmonary Function}

Pulmonary ventilation function is an important index in COPD diagnosis and treatment. Results are increased lung airway resistance $\left(R_{L}\right)$ but decreased dynamic compliance (Cdyn). $R_{L}$ and Cdyn are commonly measured by relating airflow and driving pressure. These data were calculated by measuring airway flow $(\mathrm{V})$, tidal volume $\left(\mathrm{V}_{\mathrm{t}}\right)$, and trans-pulmonary pressure (Ptp) by the formula $R_{L}=P t p / V$, Cdyn $=V_{t}$ Ptp. The breathing rate of rats was recorded by the MedLab system for 30 min and the test waveforms are shown in Figures $4 \mathbf{A}-\mathbf{C}$. Compared with the vehicle control group, $V$ and $V_{\mathrm{t}}$ were decreased in the COPD model rat, but led to a rise in Ptp. CPE $(200,400$, or $500 \mathrm{mg} / \mathrm{kg} /$ day) was given orally for 15 days and the results showed that $400 \mathrm{mg} / \mathrm{kg} /$ day dose was the best dose. The V, and Vt were markedly increased $(p<0.01)$ and Ptp was effectively lower $(p<0.05)$ after treatment (Figures 4D-F). Compared with the vehicle control group, model group rats $\mathrm{R}_{\mathrm{L}}$ increased by $67.12 \%(p<0.01)$ and Cdyn decreased by $75.14 \%$ $(p<0.01)$. In the Guilong Kechuanning capsule positive group compared with the model group, $\mathrm{R}_{\mathrm{L}}$ decreased by $26.02 \%$ and Cdyn increased by $140.40 \%(p<0.01)$. In the $400 \mathrm{mg} / \mathrm{kg}$ dose of CPE group compared with the model group, $\mathrm{R}_{\mathrm{L}}$ decreased by $36.29 \%$ and Cdyn increased by $171.30 \%(p<0.01)$. Experimental results showed that $\mathrm{CPE}$ could decrease airway resistance and increased dynamic compliance in rats with COPD (Table 4).

\section{Image Analysis of Lung Tissue Sections}

Rats were killed to obtain lung tissues when the CPE treatment concluded and the pulmonary tissue pathology was observed with HE staining. Crucial gas exchange takes place in the alveoli. There were full alveoli, respiratory ducts, peripheral, small airways that were normally present in the pulmonary parenchyma in the control group (Figure 5A). The number of alveoli was significantly decreased in the SCS group; rats with COPD had significant inflammation that was caused by inflammatory cell infiltration and damage to alveoli structure. The lung lesions were characterized by interstitial edema, the alveolar wall was thickened and there was less alveolar space. There was extensive necrotic changes of the alveoli and partial consolidation, and infiltration of inflammatory cells (Figure 5B). The lung damage treated with Guilong Kechuanning capsule (450 mg/kg/day) and CPE (400 mg/kg/day, orally) was lower than that in the model group. Image analysis suggested that $\mathrm{CPE}$ could decrease the degree of alveolar destruction $(p<0.05)$, alleviate lung inflammation, increase alveolar space, and improve infiltration of inflammatory cells in airway inflammation (Figures 5C, D).

\section{Effect of CPE on the Expression of Toll-Like Receptors and the Downstream Signaling Transduction Pathway in Rat AMs}

Effect of CPE on the Proliferation of Rats Alveolar Macrophage

CPE of different concentrations was used to treat the cells at the 24, 48 and $72 \mathrm{~h}$, and cell proliferation was observed using MTT method to evaluate the cytotoxicity of CPE to AMs. AMs proliferation rates were $100 \% 72 \mathrm{~h}$ at the CPE of $50 \mu \mathrm{g} / \mathrm{ml}$, $99.73 \% 72 \mathrm{~h}$ at the concentration of $100 \mu \mathrm{g} / \mathrm{ml}(\mathrm{P}<0.05), 99.55 \%$ $72 \mathrm{~h}$ at the concentration of $200 \mu \mathrm{g} / \mathrm{ml}(\mathrm{P}<0.05), 99.28 \% 72 \mathrm{~h}$ at the concentration of $500 \mu \mathrm{g} / \mathrm{ml}(\mathrm{P}<0.05), 95.83 \% 72 \mathrm{~h}$ at the concentration of $1,000 \mu \mathrm{g} / \mathrm{ml}(\mathrm{P}<0.05)$, and $88.08 \% 72 \mathrm{~h}$ at the 
concentration of $2,000 \mu \mathrm{g} / \mathrm{ml}(\mathrm{P}<0.05)$. When the concentration of CPE was lower than $1000 \mu \mathrm{g} / \mathrm{mL}$, the $\mathrm{CPE}$ showed no toxicity on AMs.

\section{Cytokine Measurement by ELISA in Serum and Cell Supernatants}

Medication group rats were treated with intragastric administration of CPE (200, 400, and $500 \mathrm{mg} / \mathrm{kg}$ ) once daily for 15 days. Orbital plexus blood samples were collected; serum was isolated and assayed by ELISA. AMs of each group were separated by bronchoalveolar lavage.
TNF- $\alpha$ and IL-10 cytokine in the serum were measured using ELISA. COPD model group, the level of TNF- $\alpha$ inflammatory cytokine was increased in the serum when compared to the vehicle control group $(145.34 \pm 16.92 \mathrm{pg} / \mathrm{ml} v s 97.72 \pm 6.94 \mathrm{pg} /$ $\mathrm{ml}, p<0.01)$. Treatment with CPE resulted in significant differences $(p<0.01)$ in that the concentration of TNF- $\alpha$ dropped from $145.34 \pm 16.92$ to $100.47 \pm 8.01 \mathrm{pg} / \mathrm{ml}$. However, the concentration of IL-10 anti-inflammatory cytokine was also increased in the serum of model rats $(36.57 \pm$ $1.63 \mathrm{pg} / \mathrm{ml}$ vs $29.80 \pm 0.85 \mathrm{pg} / \mathrm{ml}, p<0.01)$. Guilong Kechuanning capsule and CPE groups, the levels of serum IL-10 were markedly

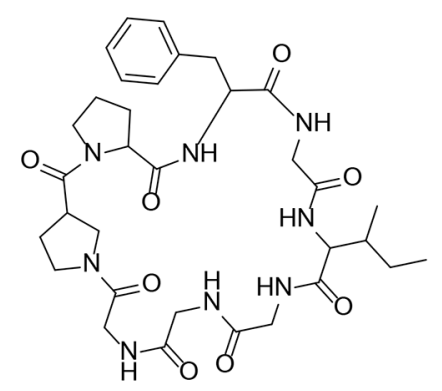

Pseudostellarin B<smiles>CCC(C)C(NC(=O)C(NC(=O)C1CCCN1C(=O)C(NC(=O)C(NC(=O)CNC(=O)C(Cc1ccccc1)N[C@H](C(C)C)C(C)CC)C(C)O)C(C)C)C(=O)NC(C(C)C)C(C)C)C(=O)NC(C(C)C)C(C)CC</smiles>

Heterophyllin A

Pseudostellarin E

\section{Pseudostellarin C}<smiles>CC(C)CC(NC(=O)C1CCCN1C(=O)CNC(=O)C(Cc1ccccc1)NC(=O)C(CO)NC(=O)C(Cc1ccccc1)NC12OC1C1CCCN1C(=O)C(C)NC(=O)C1CCCN12)C(=O)NC(Cc1ccccc1)C(=O)NC(C)C</smiles>

Pseudostellarin G

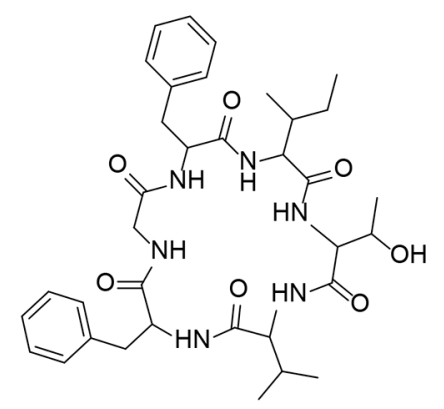

Heterophyllin D 


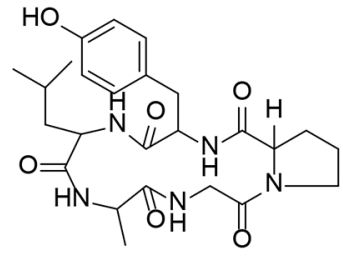

Pseudostellarin A

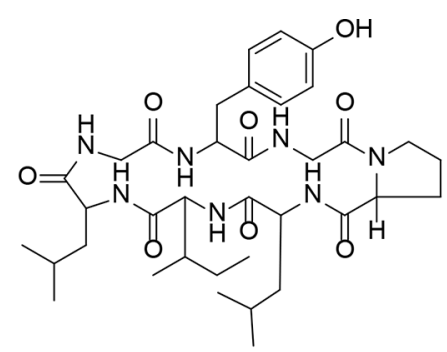

Pseudostellarin D

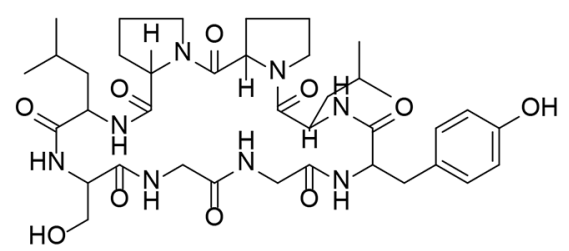

Pseudostellarin F

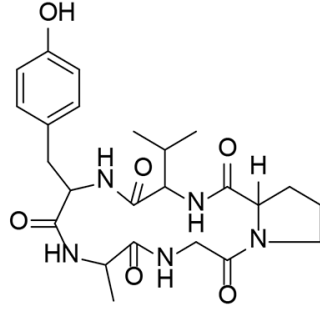

Heterophyllin $\mathbf{J}$

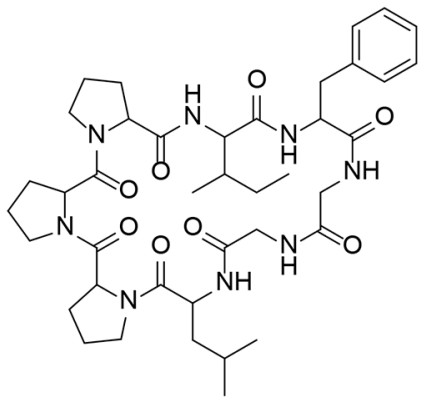

Heterophyllin B

FIGURE 3 | The structures of 11 kinds of cyclic peptide monomers.

TABLE 3A | Effects of CPE on hematological indexes in rats $(\bar{x} \pm s d)$.

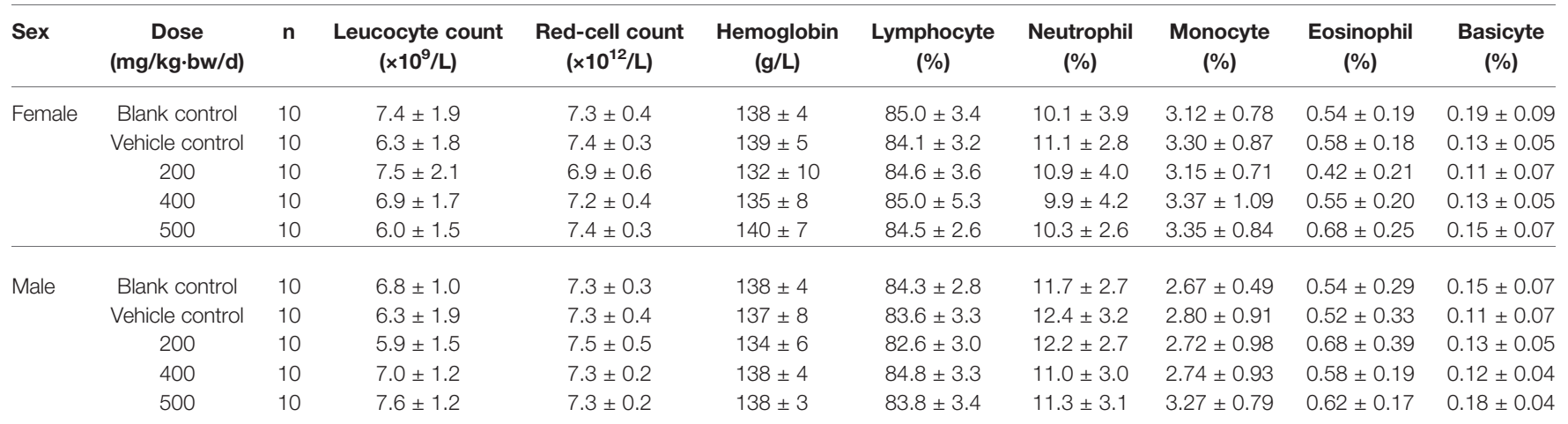


TABLE 3B | Effects of CPE on blood biochemical indexes in rats $(\bar{x} \pm s d)$.

\begin{tabular}{|c|c|c|c|c|c|c|c|c|c|c|}
\hline Sex & $\begin{array}{c}\text { Dose } \\
(\mathrm{mg} / \mathrm{kg} \cdot \mathrm{bw} / \mathrm{d})\end{array}$ & $\mathbf{n}$ & $\begin{array}{c}\text { Alanine } \\
\text { transaminase } \\
(\mathrm{U} / \mathrm{L})\end{array}$ & $\begin{array}{c}\text { Aspertate } \\
\text { Aminotransferase } \\
\text { (U/L) }\end{array}$ & $\begin{array}{l}\text { Total protein } \\
(\mathrm{g} / \mathrm{L})\end{array}$ & $\begin{array}{l}\text { Albumin } \\
\text { (g/L) }\end{array}$ & $\begin{array}{l}\text { Blood urea } \\
\text { nitrogen } \\
\text { (mmol/L) }\end{array}$ & $\begin{array}{l}\text { Creatinine } \\
(\mu \mathrm{mol} / \mathrm{L})\end{array}$ & $\begin{array}{c}\text { Total } \\
\text { cholesterol } \\
\text { (mmol/L) }\end{array}$ & $\begin{array}{c}\text { Triglyceride } \\
\text { (mmol/L) }\end{array}$ \\
\hline \multirow[t]{5}{*}{ Female } & Blank control & 10 & $32 \pm 2$ & $115 \pm 18$ & $54.2 \pm 1.9$ & $32.9 \pm 1.9$ & $5.84 \pm 0.91$ & $33 \pm 5$ & $1.88 \pm 0.32$ & $0.40 \pm 0.09$ \\
\hline & Vehicle control & 10 & $34 \pm 6$ & $112 \pm 20$ & $53.3 \pm 2.7$ & $32.7 \pm 1.5$ & $5.79 \pm 0.85$ & $33 \pm 4$ & $1.93 \pm 0.27$ & $0.37 \pm 0.17$ \\
\hline & 200 & 10 & $31 \pm 5$ & $95 \pm 19$ & $54.2 \pm 3.0$ & $33.1 \pm 1.3$ & $5.86 \pm 1.03$ & $36 \pm 6$ & $1.96 \pm 0.29$ & $0.31 \pm 0.05$ \\
\hline & 400 & 10 & $30 \pm 3$ & $102 \pm 10$ & $55.1 \pm 1.5$ & $33.4 \pm 1.0$ & $5.47 \pm 1.08$ & $32 \pm 6$ & $1.98 \pm 0.33$ & $0.39 \pm 0.09$ \\
\hline & 500 & 10 & $32 \pm 4$ & $112 \pm 15$ & $54.4 \pm 2.3$ & $33.1 \pm 1.1$ & $5.86 \pm 0.84$ & $33 \pm 6$ & $2.04 \pm 0.35$ & $0.33 \pm 0.07$ \\
\hline \multirow[t]{5}{*}{ Male } & Blank control & 10 & $39 \pm 4$ & $129 \pm 32$ & $53.2 \pm 1.2$ & $31.9 \pm 0.6$ & $4.65 \pm 0.59$ & $24 \pm 2$ & $1.39 \pm 0.28$ & $0.48 \pm 0.06$ \\
\hline & Vehicle control & 10 & $41 \pm 8$ & $142 \pm 34$ & $54.1 \pm 1.6$ & $32.3 \pm 0.7$ & $5.21 \pm 0.82$ & $28 \pm 9$ & $1.46 \pm 0.29$ & $0.43 \pm 0.27$ \\
\hline & 200 & 10 & $44 \pm 2$ & $159 \pm 41$ & $52.7 \pm 1.9$ & $31.6 \pm 0.8$ & $5.86 \pm 1.03$ & $36 \pm 6$ & $1.96 \pm 0.29$ & $0.31 \pm 0.05$ \\
\hline & 400 & 10 & $37 \pm 4$ & $127 \pm 20$ & $54.3 \pm 1.6$ & $32.3 \pm 0.6$ & $4.84 \pm 0.52$ & $25 \pm 3$ & $1.36 \pm 0.30$ & $0.47 \pm 0.08$ \\
\hline & 500 & 10 & $38 \pm 7$ & $134 \pm 21$ & $54.5 \pm 1.8$ & $32.4 \pm 1.0$ & $4.83 \pm 0.68$ & $26 \pm 2$ & $1.40 \pm 0.35$ & $0.45 \pm 0.07$ \\
\hline
\end{tabular}
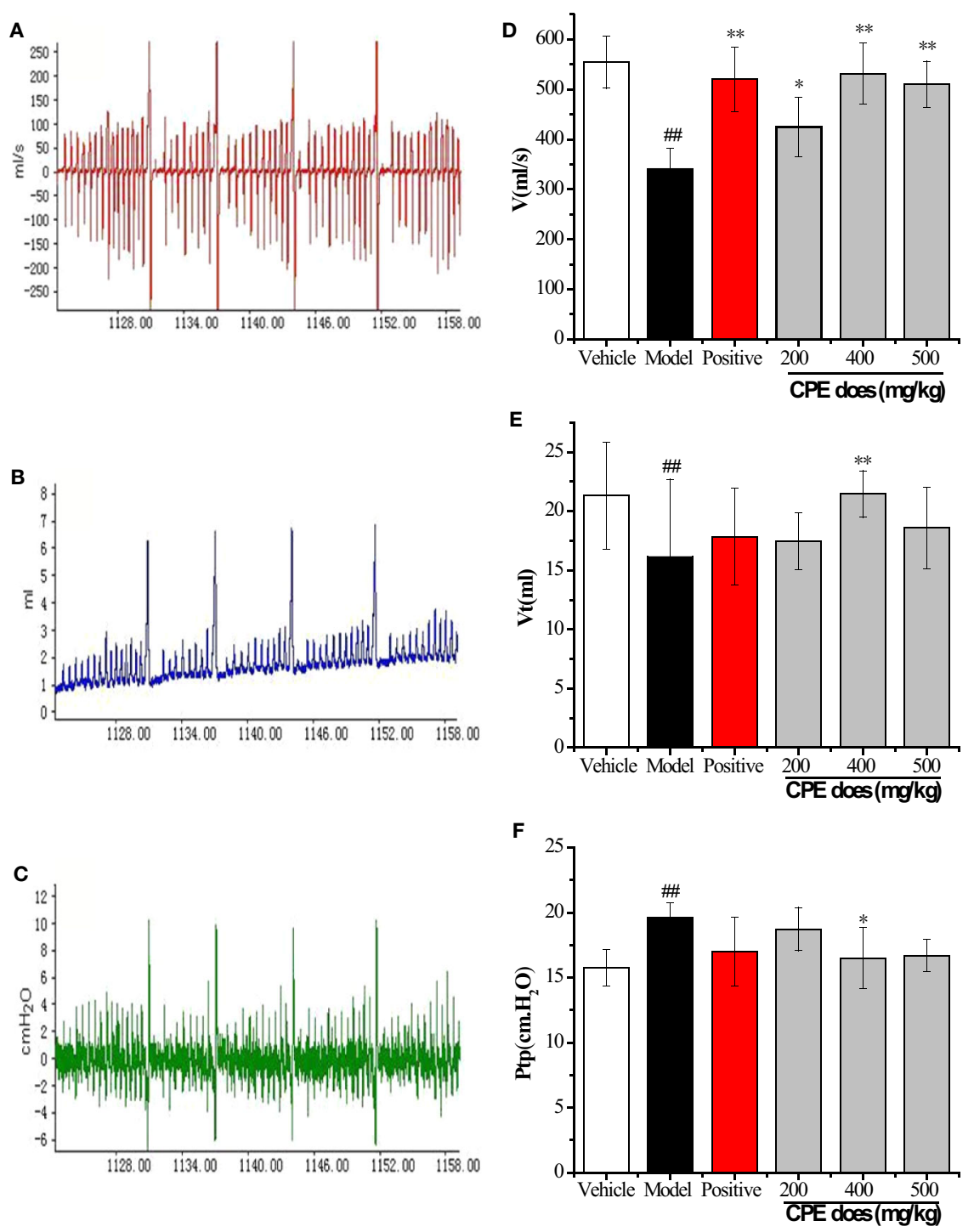

FIGURE 4 | Results of pulmonary function parameters test. (A) The test waveforms of airway flow, (B) tidal volume, and (C) trans-pulmonary pressure; (D) the test results in airway flow, (E) tidal volume, and (F) trans-pulmonary pressure; The measurements were used to calculate $R_{L}$ and $C d y n$. ${ }^{*} p<0.05$, ${ }^{\star \star} p<0.01$, compared with COPD model; ${ }^{\#} p<0.05,{ }^{\# \#} p<0.01$, compared with vehicle control, $(\bar{x} \pm s d, n=10)$. 
TABLE 4 | Changes of airway resistance and dynamic compliance in rats.

\begin{tabular}{|c|c|c|c|c|c|}
\hline Groups & $\begin{array}{c}V \\
(\mathrm{ml} / \mathrm{s})\end{array}$ & $\begin{array}{l}\text { Vt } \\
(\mathrm{ml})\end{array}$ & $\begin{array}{c}\text { Ptp } \\
(\mathrm{cm} \cdot \mathrm{H} 2 \mathrm{O})\end{array}$ & $\begin{array}{c}\mathbf{R}_{\mathrm{L}} \\
\left(\mathrm{cm} \cdot \mathrm{H}_{2} \mathrm{O} \cdot \mathrm{s} / \mathrm{ml}\right)\end{array}$ & $\begin{array}{c}\text { Cdyn } \\
\left(\mathrm{ml} / \mathrm{cm} \cdot \mathrm{H}_{2} \mathrm{O}\right)\end{array}$ \\
\hline Vehicle & $554.23 \pm 53.96$ & $21.31 \pm 4.42$ & $15.77 \pm 1.39$ & $0.028 \pm 0.001$ & $1.351 \pm 0.459$ \\
\hline Model & $340.82 \pm 39.30 \wedge \mathbf{\Delta}$ & $16.13 \pm 6.59 \wedge$ & $19.60 \pm 1.05 \wedge$ & $0.057 \pm 0.005 \wedge$ & $0.823 \pm 0.269 \wedge \wedge$ \\
\hline Positive & $519.85 \pm 63.82^{\star \star}$ & $17.84 \pm 4.06$ & $16.70 \pm 3.01^{\star}$ & $0.033 \pm 0.007^{\star \star}$ & $1.050 \pm 0.279^{\star}$ \\
\hline CPE-LD & $514.56 \pm 73.71^{\star \star}$ & $17.46 \pm 2.36$ & $18.72 \pm 1.74$ & $0.036 \pm 0.006^{\star}$ & $0.933 \pm 0.422^{\star}$ \\
\hline CPE-MD & $530.96 \pm 60.12^{\star \star}$ & $21.45 \pm 2.00^{\star \star}$ & $16.49 \pm 2.37^{\star}$ & $0.031 \pm 0.005^{\star \star}$ & $1.301 \pm 0.337^{\star \star}$ \\
\hline CPE-HD & $509.98 \pm 44.23^{\star \star}$ & $18.59 \pm 3.41^{\star}$ & $16.70 \pm 1.21^{*}$ & $0.033 \pm 0.008^{\star \star}$ & $1.113 \pm 0.471^{\star}$ \\
\hline
\end{tabular}

Values are expressed as $\bar{x} \pm s d, \mathrm{n}=10$.

$\Delta P \leq 0.05$ vs vehicle control, $\Delta \Delta P \leq 0.01$ vs vehicle control.

${ }^{*} P \leq 0.05$ vs COPD model, ${ }^{* *} P \leq 0.01$ vs COPD model.
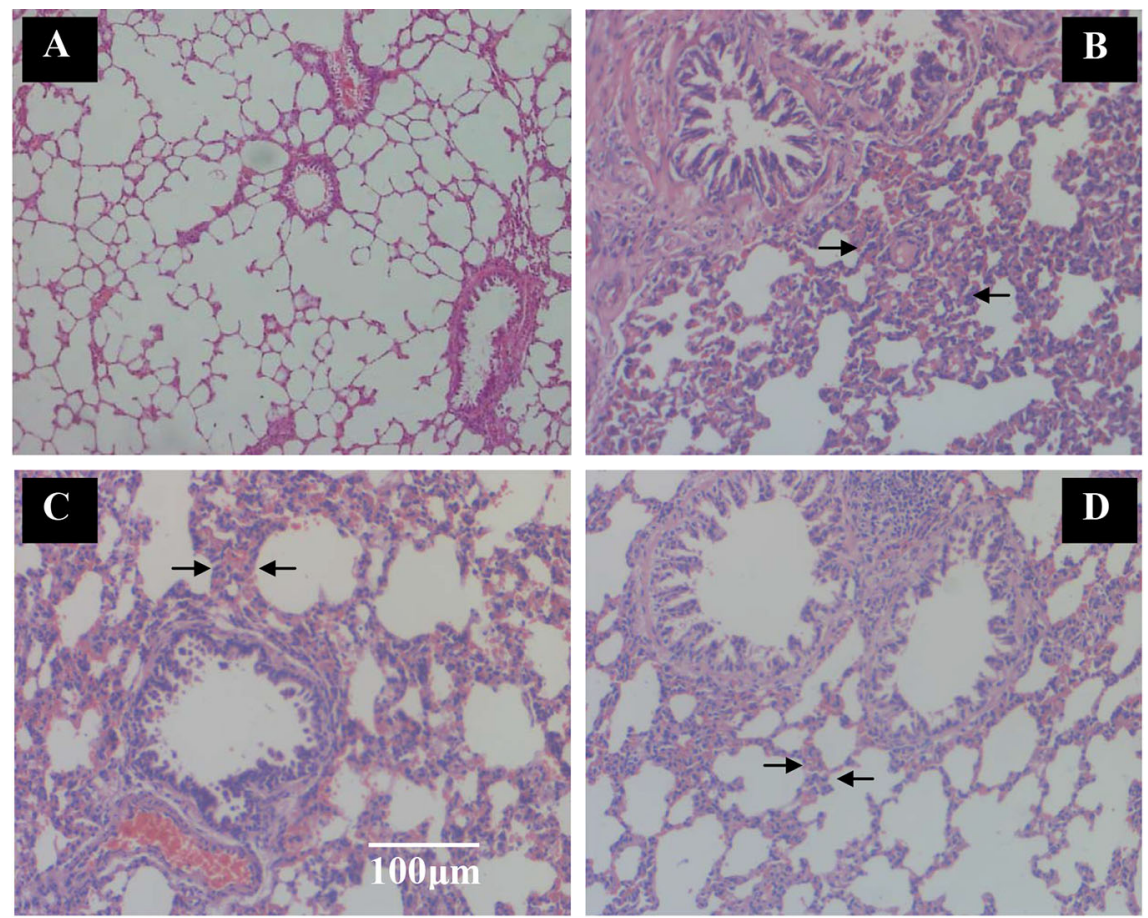

FIGURE 5 | The effect of TZS extracts on alveoli and inflammatory cell infiltration in lungs in SCS-induced rats (hematoxylin and eosin stain). Vehicle control group and model group rats treated with saline, positive control group rats treated with Guilong Kechuanning capsule (450mg/kg/day) and drug group treated with CPE (400 mg/kg/day, orally) was given to SCS-induced rats, tissue histological examination were assessed. (A) Vehicle control group, (B) SCS model group, (C) positive control group and (D) CPE treatment group. Arrows indicate alveoli space and inflammatory cell infiltration. With CPE medication, alleviate the lung inflammation, more alveolar space and the infiltrations of inflammatory cells were improved, magnification $\times 100$.

increased to $43.13 \pm 2.70$ and $55.72 \pm 2.67 \mathrm{pg} / \mathrm{ml}$, respectively $(p<0.01)$. For treatment with the positive control and CPE, levels of TNF- $\alpha$ decreased, but IL-10 increased, suggesting that they have obvious anti-inflammatory effects. A CPE dose of $400 \mathrm{mg} / \mathrm{kg}$ was the best and its curative effect was better than the positive control (Figure 6A).

After treatment of CPE, pulmonary alveolar macrophages (AMs) of all experiment group rats were separated by bronchoalveolar lavage fluid extraction. AMs were stimulated with lipopolysaccharide (LPS) (end concentration $0.1 \mu \mathrm{g} / \mathrm{ml}$ ) and cultured with RPMI-1640 containing 10\% FBS medium for different time $(12,24$, or $48 \mathrm{~h})$, AMs separated by normal and model groups rat served as controls. The levels of TNF- $\alpha$ and IL10 in the AMs supernatant were detected by ELISA. The level of TNF- $\alpha$ was decreased treatment with CPE, but increased level of IL-10 in supernatant. AMs isolated from rats were treated with $400 \mathrm{mg} / \mathrm{kg}$ of CPE (CPE-MD) and cultured for $24 \mathrm{~h}$ that it was the best results. The concentration of TNF- $\alpha$ and IL-10 in the supernatant of AMs (vehicle or model group) was $26.37 \pm 2.10$, $96.79 \pm 3.18,244.59 \pm 8.43$, and $142.77 \pm 6.28 \mathrm{pg} / \mathrm{ml}$. CPE-MD group, they were $27.94 \pm 2.15$ and $241.57 \pm 7.20 \mathrm{pg} / \mathrm{ml}$; respectively. More detailed data are illustrated in Figures 6B, C. 

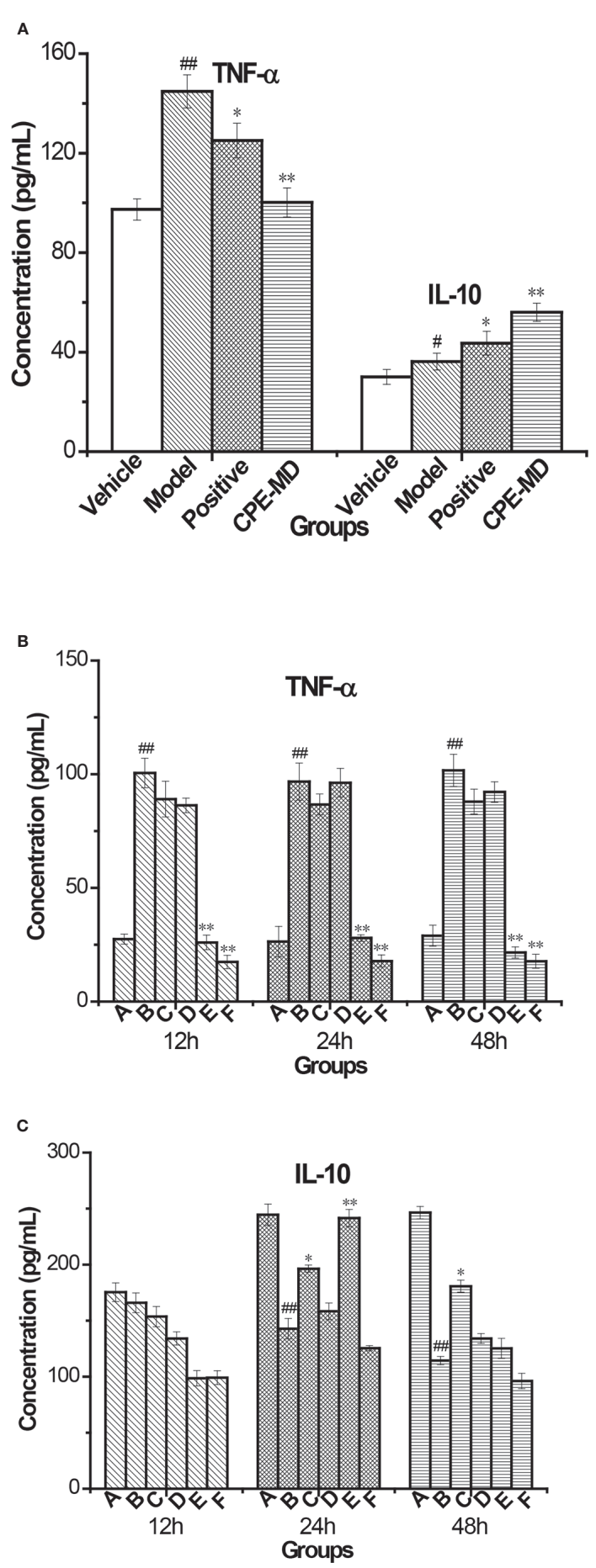

FIGURE 6 | Changes of cytokine in rat serum and supernatant of AMs with COPD model treatment with CPE. (A) TNF- $\alpha$ and IL-10 level in rat serum $(\bar{x} \pm s d, n=10)$. (B) TNF- $\alpha$ level and (C) IL-10 level in supernatant of AMs. ${ }^{*} \mathrm{p}<0.05,{ }^{* *} \mathrm{p}<0.01$, compared with COPD model; ${ }^{\#} \mathrm{p}<0.05$, ${ }^{\# \#} \mathrm{p}<0.01$, compared with vehicle control; A-Vehicle control, B-COPD model + LPS, C-positive + LPS, D-CPE-LD + LPS, E-CPE-MD + LPS, F-CPE-HD + LPS; ${ }^{*} p<0.05$, ${ }^{* *} p<0.01$, compared with COPD model; ${ }^{*} p<0.05$, $\# \mathrm{p}<0.01$, compared with vehicle control, $(\bar{x} \pm s d, n=6)$.

\section{Expression of TLR4 mRNA and MyD88 mRNA of AMs by RT-PCR}

An AM cell line was stimulated with LPS and cultured with RPMI 1640 containing 10\% FBS medium. Twenty-four hours later, RNA of AMs was extracted and TLR4 mRNA MyD88 mRNA, and AP-1 mRNA levels were determined with relative quantification using the $2^{-\triangle \triangle \mathrm{Ct}}$ method.

TLR4 mRNA expression in the COPD model group was $2.98 \pm 0.13$, which was remarkably increased compared to the vehicle control group $(1.00 \pm 0.00, p<0.01)$. CPE could attenuate the expression of TLR4 mRNA in COPD rats. TLR4 mRNA levels were $2.09 \pm 0.18$ for the CPE-LD group, $1.10 \pm 0.10$ for the CPE-MD group, and $1.09 \pm 0.22$ for the CPE-HD group. TLR4 mRNA expression was decreased $(p<0.01)$ after using CPE-MD or CPE-HD, while it increased in the CPE-LD group $(p<0.05)$.

MyD88 mRNA expression in AMs of the COPD rats (3.08 \pm $0.22)$ was increased compared to that of vehicle groups $(1.26 \pm 0.28)$. In the CPE-LD group it was $2.58 \pm 0.26,1.33 \pm 0.16$ in the CPE-MD group, and $1.57 \pm 0.10$ in the CPE-HD group. The MyD88 mRNA expression was decreased $(p<0.01)$ after using CPE-MD or CPE$\mathrm{HD}$, while it increased in the CPE-LD group $(p<0.05)$.

AP-1 mRNA expression in AMs of the COPD rats (1.22 \pm $0.05)$ was increased compared to that of vehicle groups (1.00 \pm $0.00)$. In the CPE-LD group it was $1.13 \pm 0.05,1.08 \pm 0.11$ in the CPE-MD group, and $1.09 \pm 0.08$ in the CPE-HD group. The AP- 1 mRNA expression was decreased $(p<0.05)$ after using CPE-MD or CPE-HD, but not significantly difference with CPE-LD group.

CPE reduced the mRNA level of TLR4, MyD88, and AP-1 exerted anti-inflammatory effects, and simultaneously resistance LPS infection to stimulus. Vehicle control values of TLR4, MyD88 and AP-1 were expressed as 1.0. Results were listed in Table 5.

\section{Levels of p-p38, p-JNK, p-IKK, p-IKB, p-TAK1, and AP-1 in AMs by WB}

An AM cell line was stimulated with LPS and cultured with RPMI 1640 containing 10\% FBS medium. Twenty-four hours later, total protein was extracted. Western blot was used to determine the total protein levels of p38, JNK, IKK and levels of phosphorylated IKK, JNK, and p38 in whole-cell lysates. The expression of p-IKB protein was unstable in AMs. Compared with the vehicle control group, the protein levels of p-p38, p-JNK, p-IKK, p-TAK1, and AP-1 were significantly increased in the COPD model group while the expression of $\mathrm{p}-\mathrm{IKK}$ in the CPE group was not significantly

TABLE 5 | Effect of CPE on the expression of TLR 4 mRNA, MyD88 and AP-1 mRNA in AMs.

\begin{tabular}{|c|c|c|c|}
\hline Groups & $2^{-\triangle \triangle c t}($ TLR4) & $2^{-\triangle \triangle c t}$ (MyD88) & $2^{-\triangle \triangle c t}(A P-1)$ \\
\hline Vehicle & $1.00 \pm 0.00$ & $1.00 \pm 0.00$ & $1.00 \pm 0.00$ \\
\hline Model & $2.98 \pm 0.13 \mathbf{\Lambda}$ & $2.44 \pm 0.17 \boldsymbol{\Lambda} \boldsymbol{\Lambda}$ & $1.22 \pm 0.05^{\boldsymbol{\Lambda}}$ \\
\hline Positive & $1.74 \pm 0.19^{\star \star}$ & $1.41 \pm 0.12^{\star \star}$ & $1.19 \pm 0.07$ \\
\hline CPE-LD & $2.09 \pm 0.18^{\star}$ & $2.05 \pm 0.21^{*}$ & $1.13 \pm 0.05$ \\
\hline CPE-MD & $1.10 \pm 0.10^{\star \star}$ & $1.06 \pm 0.13^{\star \star}$ & $1.08 \pm 0.11^{*}$ \\
\hline CPE-HD & $1.09 \pm 0.22^{\star \star}$ & $1.25 \pm 0.08^{\star \star}$ & $1.09 \pm 0.08^{\star}$ \\
\hline
\end{tabular}

Values are expressed as $\bar{x} \pm s d, \mathrm{n}=6$.

$\Delta P \leq 0.05$ vs vehicle control, $\Delta \Delta^{\Delta} \leq 0.01$ vs vehicle control.

${ }^{*} P \leq 0.05$ vs COPD model, ${ }^{* *} P \leq 0.01$ vs COPD model. 
decreased compared to the model group $(p>0.05)$. $\mathrm{p}$-JNK proteins in the CPE-LD, CPE-MD, and CPE-HD groups were significantly decreased compared with the COPD model group $(p<0.01)$ and p-p38 proteins in the CPE-MD, and CPE-HD groups were significantly decreased compared with the COPD model group $(p<0.01)$. AP-1 protein in the CPE-MD group was decreased compared with the COPD model group $(p<0.05)$. p-TAK1 proteins in the CPE-MD and CPE-HD groups were significantly decreased compared with the COPD model group $(p<0.01)$.

$\mathrm{CPE}$ reduced the proteins level of $\mathrm{p}-\mathrm{JNK}$, p-p38, p-TAK1, and AP-1 exerted anti-inflammatory effects, and simultaneously resistance LPS infection to stimulus. The levels of $\mathrm{p}-\mathrm{IKK}, \mathrm{p}-\mathrm{JNK}, \mathrm{p}-\mathrm{p} 38$, $\mathrm{p}-$ TAK1, and AP-1 have been normalized by the levels of the corresponding total protein and expressed relative to the phosphorylation ratio in vehicle-treated cells (see in Figures 7 and 8).

\section{DISCUSSION}

COPD is a public health problem. It exhibits symptoms of chronic bronchitis and emphysema, which causes the characteristic narrow airways and shortness of breath in patients. COPD drug therapy, including bronchodilators, anti-inflammatory agent, antioxidant, protease inhibitors, antibiotics, etc; but has a poor prognosis, at present there is no specific way to make COPD are completely curable. The primary aim of COPD treatment is to

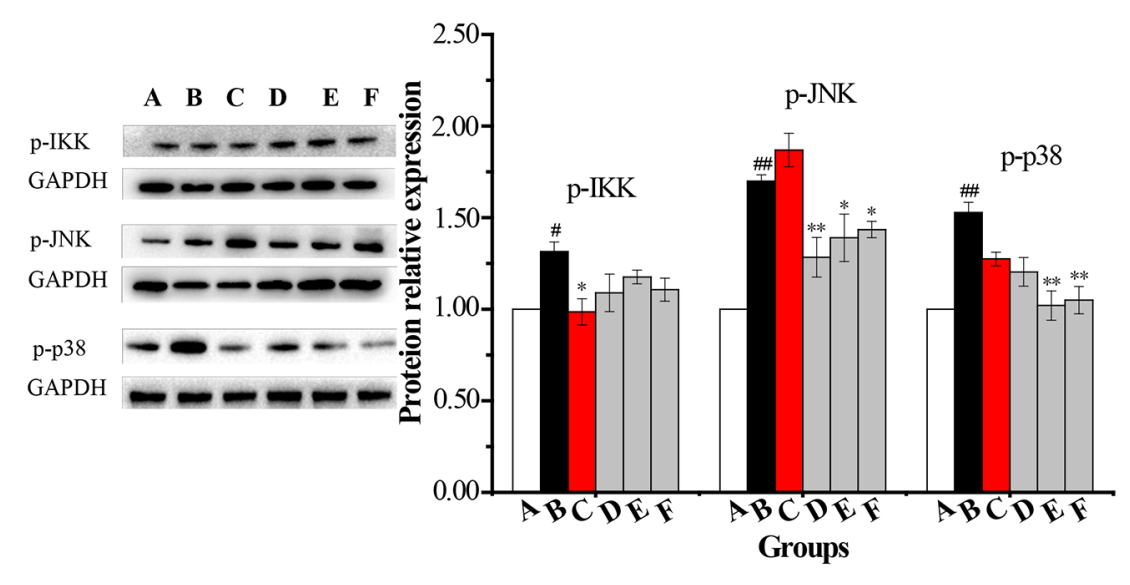

FIGURE 7 | The changes in expression levels of p-IKK, p-JNK and p-p38 in rat alveolar macrophages after the treatment with CPE. A-vehicle control, B-COPD model + LPS, C-positive + LPS, D-CPE-LD + LPS, E-CPE-MD + LPS, F-CPE-HD + LPS; ${ }^{p} p<0.05,{ }^{* *} p<0.01$, compared with COPD model; ${ }^{*} p<0.05$, $\# \mathrm{p}<0.01$, compared with vehicle control, $(\bar{x} \pm s d, n=6)$.

FIGURE 8 | The changes in expression levels of AP-1 and p-TAK1 in rat alveolar macrophages after the treatment with CPE. A-vehicle control, B-COPD model + LPS, C-positive + LPS, D-CPE-LD + LPS, E-CPE-MD + LPS, F-CPE-HD + LPS; ${ }^{*} p<0.05,{ }^{* *}$ p < 0.01, compared with COPD model; ${ }^{\#}$ p < 0.05, \#\# $<<0.01$, compared with vehicle control, $(\bar{x} \pm s d, n=6)$. 
control symptoms, reduce the rate of deterioration and mortality, and improve the quality of life of patients (Fujii et al., 1999; Puljic et al., 2007; Wollin and Pieper, 2010; Zeng et al., 2010).

TNF- $\alpha$ is a pro-inflammatory cytokine that is closely correlated with pulmonary inflammation caused by COPD. IL10 decreases pulmonary neutrophilia and also suppresses the expression of TNF- $\alpha$, IL-6, and IL-8 (Pelaia et al., 2006). TLR4 mediates pathogen-induced NF- $\kappa \mathrm{B}$ activation in endothelial cells through the homologous structure of the intracellular interleukin1 receptor (IL-1R) followed by downstream signaling of MyD88, which then secretes immune inflammatory cytokines, and thereby causes COPD. With better understanding of the COPD inflammatory mechanisms, broad spectrum anti-inflammatory drugs may be more effective, such as inhibitors of PDE4, p38 MAPK and NF- $\mathrm{BB}$, some data suggest that anti-inflammatory therapies might provide a way to prevent COPD condition worsens (Barnes, 2008).

Natural medicinal or Chinese medicine displays a unique chemical diversity and diversity of the biological activities which is one of the most important resources of novel lead compounds especially for the critical diseases. The research on active constituent of natural or traditional medicine is known as one of important means of developing new drugs.

TZS is a Chinese herb that resists pulmonary diseases. We previously showed that the ethyl acetate extract of TZS relieves cough and improves lung function via adjustment of the levels of multiple cytokines (Pang et al., 2011). The ethyl acetate extract of TZS is rich in cyclic-peptides; the activity of these cyclic-peptide fractions is not clear.

Cyclic peptides are the substances which are Head-totail cyclization refers to the formation of an amide bond between the C-terminal carboxylic acid and N-terminal amine of the peptide. Cyclic peptides possess diverse biological activities such as antibacterial, anticancer, antifungal, antiviral, and antiinflammatory properties. More than 40 cyclic peptide drugs have been clinically approved, the most of which are derived from natural world. But some cyclic peptides there are problems with the metabolic stability and oral absorption limits their development as drug candidates (Jing and Jin, 2020).

In this paper, the ethyl acetate extract of TZS was purified that degreased with petroleum ether, amino acids were removed with hot water, and polysaccharide and other impurities were removed with alcohol-precipitation. The purity of CPE after purification is up to $92.94 \%$.

Our research provides further evidence for $P$. heterophylla (Miq.) Pax. CPE prevents alveolar destruction and alleviating lung inflammation in COPD rats induced by SCS. The release of the pro-inflammatory cytokine TNF- $\alpha$ was significantly inhibited, while the anti-inflammatory cytokine IL-10 was increased in serum. These results are closely associated with airflow limitation in the COPD rat.

TLR4 and MyD88 expression was determined using SYBR Green I by real-time PCR. AMs were stimulated by LPS, the expressions of TLR4, MyD88 and p-JNK and p-p38 were enhanced, showing remarkably higher in COPD groups than normal control groups. Upon activation by LPS, TLR4 can form a dimer to recruit MyD88 and/or TRIF, and then bind with IRAK4 to enable IRAK1 to recruit TRAF6. The IRAK1-TRAF6 complex phosphorylates TAB2/TAB3 and TAK1 and thus activates the IKK and MAPK signaling pathways. JNK and p38 MAPK activation initiate the transcriptional potential of c-Jun or c-fos, a critical part of AP-1. After medication, the expression levels of TLR4 mRNA and MyD88 mRNA, and p-JNK and p-p38 were significantly down-regulated. Our experiments have proved that CPE inhibited TAK1 phosphorylation and effectively downregulating the expression of $\mathrm{AP}-1$. $\mathrm{CPE}$ intervention could improve pathological changes of the pulmonary ventilation function in COPD rats, which may be related to its effect in inhibiting abnormal activation of the TLR4-MyD88-JNK/p38 signal transduction pathway.

\section{CONCLUSION}

In conclusion, we studied the CPE of TZS that it prevented alveolar destruction and alleviated lung airway inflammation by inhibiting inflammatory cytokine levels via the regulation of the TLR4/MyD88 pathway and its related proteins in COPD rats. This is the first report on cyclic peptides extracted from $P$. heterophylla lessens the severity of COPD episodes. The results of studies will be helpful to develop potential anti-COPD cyclic peptide drugs and solve tricky medical problems by stealing an idea from nature.

\section{DATA AVAILABILITY STATEMENT}

The datasets generated for this study are available on request to the corresponding authors.

\section{ETHICS STATEMENT}

The animal study was reviewed and approved by Ethics committee on experimental animals of Fujian Academy of Traditional Chinese Medicine No. FJATCM-IAEC2017012.

\section{AUTHOR CONTRIBUTIONS}

FL: research. HY: separation experiment. S-DL: HPLC analysis and pharmacological experiments. LZ: UPLC/MS/MS analysis and pharmacological experiments. CJ: HPLC analysis and pharmacological experiments. Z-BC: statistical analysis. Y-YL: cell experiment and q-PCR assay. Y-JK: The safety evaluating and western blotting analysis. JH: project management and thesis writing. W-SP: CPE preparation methodology research.

\section{FUNDING}

The authors gave thanks to Project 81673575 , supported by the National Natural Science Foundation of China; the authors gave thanks to Project 2019YFC1710504, supported by the National Key R \& D Plans. 


\section{REFERENCES}

Barnes, P. J. (2004). Mediators of Chronic Obstructive Pulmonary Disease. Pharmacol. Rev. 56 (4), 515-548. doi: 10.1124/pr.56.4.2

Barnes, P. J. (2008). Frontrunners in novel pharmacotherapy of COPD. Curr. Opin. Pharmacol. 8 (3), 300-307. doi: 10.1016/j.coph.2008.03.001

Bruno, C. M., and Valenti, M. (2012). Acid-Base Disorders in Patients with Chronic Obstructive Pulmonary Disease: A Pathophysiological Review. J. Biomed. Biotechnol. 2012, 1-8. doi: 10.1155/2012/915150. Article ID 915150,.

David, M. M., and Victor, A. K. (2006). Changing the burden of COPD mortality. Int. J. Chronic. Obstr. 1 (3), 219-233. doi: 10.2147/copd.2006.1.3.219

Di Stefano, A., Ricciardolo, F. L. M., Caramori, G., Adcock, I. M., Chung, K. F., Barnes, P. J., et al. (2017). Bronchial inflammation and bacterial load in stable COPD is associated with TLR4 overexpression. Eur. Respir. J. 49 (5), 16020061602006, 11. doi: 10.1183/13993003.02006-2016

Franco, D. P., Valerie, F. J. Q., and Bernhard, R. (2018). MyD88 as a therapeutic target for inflammatory lung diseases. Expert. Opin. Ther. Tar. 22 (5), 401-408. doi: 10.1080/14728222.2018.1464139

Fu, X. S., Liu, X. H., Xu, H., Zhou, Y. Z., and Chen, F. (2012). Research status and trends of pseudostellariae radix. Chin. J. New Drugs 21 (7), 757-760.

Fujii, T., Otsuka, T., Tanaka, S., Kanazawa, H., Hirata, K., Kohno, M., et al. (1999). Plasma endothelin-1 level in chronic obstructive pulmonary disease: relationship with natriuretic peptide. Respiration 66 (3), 212-219. doi: 10.1159/000029380

Hsu, D. Z., Liu, C. T., Chu, P. Y., Li, Y. H., Periasamy, S., and Liu, M. Y. (2013). Sesame Oil Attenuates Ovalbumin-Induced Pulmonary Edema and Bronchial Neutrophilic Inflammation in Mice. BioMed. Res. Int. 2013, 1-7. doi: 10.1155/ 2013/905670. Article ID 905670,.

Hua, Y. J., Wang, S. N., Chai, C., Liu, Z. X., Liu, X. H., Zou, L. S., et al. (2017). Quality Evaluation of Pseudostellariae Radix Based on Simultaneous Determination of Multiple Bioactive Components Combined with Grey Relational Analysis. Molecules 22 (1), 13-28. doi: 10.3390/Molecules22010013

Huang, X. X., and Cai, J. K. (1993). Effect of Guilong Kechuanning on 1468 Cases of Pulmonary Diseases. Jiangsu J. Tradit. Chin. Med. Sum 495 (11), 15.

Huang, W. Z., Liu, Y., Qin, M. J., and Dou, C. G. (2005). The evaluation of immunifaction of extract from Pseudostellaria heterophylla in mice. Res. Pract. Chin. Med. 19 (6), 35-37.

Huang, C. Y., Pan, L. H., Lin, F., Qian, W., and Li, W. (2015). Alveolar macrophage TLR4/MyD88 signaling pathway contributes to ventilator-induced lung injury in rats. Chin. J. Cell. Mol. Immunol. 31 (2), 182-189.

Jiangsu New Medical College (1977). Encyclopedia of Chinese Materia Medica (Appendix) (Shanghai, China: Shanghai People's Press), 595-596.

Jing, X. S., and Jin, K. (2020). A gold mine for drug discovery: Strategies to develop cyclic peptides into therapies. Med. Res. Rev. 40 (2), 753-810. doi: 10.1002/med.21639

Ley, Z. J., Ley, S., and Kauczor, H. U. (2008). Morphological and functional imaging in COPD with CT and MRI: present and future. Eur. Radiol. 18, 510521. doi: $10.1007 / \mathrm{s} 00330-007-0772-1$

Li, T. Z., Chen, Z. T., and Peng, J. (2005). Effect of the therapy Shenyi capsules and Guilongkechuanning capsules on the cellular immunologic function and cytotines in patients with chronic obstructive pulmonary disease. Chin. Chongqing Med. 34 (1), 78-82.

Lin, G. M. (2004). Progress in study of Chinese herb Taizishen. Chin Wild Plant Resour. 23 (6), 15-17.

Lindberg, A., Larsson, L. G., Muellerova, H., Rönmark, E., and Lundbäck, B. (2012). Up-to-date on mortality in COPD-report from the OLIN COPD study. BMC Pulm. Med. 12, 1-7. doi: 10.1186/1471-2466-12-1

Murărescu, E. D., Eloae-zugun, F., and Mihailovici, M. S. (2008). Experimental COPD induced by solid combustible burn smoke in rats: a study of the emphysematous changes of the pulmonary parenchyma. Rom. J. Morphol. Embryo. 49 (4), 495-505.

Ng, T. B., Liu, F. H., and Wang, X. (2004). The antioxidant effects of aqueous and organic extracts of Panax quinquefolium, Panax notoginseng, Codonopsis pilosula, Pseudostellaria heterophylla and Glehnia littoralis. J. Ethnopharmacol. 93 (2), 285-288. doi: 10.1016/j.jep.2004.03.040

Pang, W. S., Lin, S. D., Dai, Q. W., Zhang, H. C., and Hu, J. (2011). Antitussive Activity of Pseudostellaria heterophylla (Miq.) Pax Extracts and Improvement in Lung Function via Adjustment of Multi-Cytokine Levels. Molecules 16, 3360-3370. doi: 10.3390/molecules 16043360

Pelaia, G., Vatrella, A., Gallelli, L., Renda, T., Caputi, M., Maselli, R., et al. (2006). Biological targets for therapeutic interventions in COPD: clinical potential. Int. J. Chronic. Obstr. 1 (3), 321-334. doi: 10.2147/copd.2006.1.3.321

Puljic, R., Benediktus, E., Plater-Zyberk, C., Baeuerle, P. A., Szelenyi, S., Brune, K., et al. (2007). Lipopolysaccharide-induced lung inflammation is inhibited by neutralization of GM-CSF. Eur. J. Pharmacol. 557 (2-3), 230-235. doi: 10.1016/ j.ejphar.2006.11.023

Valença, S. S., de Souza da Fonseca, A., da Hora, K., Santos, R., and Porto, L. C. (2004). Lung morphometry and MMP-12 expression in rats treated with intraperitoneal nicotine. Exp. Toxicol. Pathol. 55 (5), 393-400. doi: 10.1078/ 0940-2993-00322

Wang, H. X., and Ng, T. B. (2006). Concurrent isolation of a Kunitz-type trypsin inhibitor with antifungal activity and a novel lectin from Pseudostellaria heterophylla roots. Biochem. Bioph. Res. Co. 342 (1), 349-353. doi: 10.1016/ j.bbrc.2006.01.109

Weibel, E. R., and Gomez, D. M. (1962). A principle for counting tissue structures on random sections. J. Appl. Physiol. 17 (2), 1343-1348. doi: 10.1152/ jappl.1962.17.2.343

Wollin, L., and Pieper, M. P. (2010). Tiotropium bromide exerts antiinflammatory activity in a cigarette smoke mouse model of COPD. Pulm. Pharmacol. Ther. 23 (4), 345-354. doi: 10.1016/j.pupt.2010.03.008

Wong, C. K., Leung, K. N., and Fung, M. C. (1994). The induction of cytokine gene expression in murine peritoneal macrophages by Pseudostellaria heterophylla. Immunopharm. Immunot. 16 (3), 347-357. doi: 10.3109/08923979409007098

Yan, C. G. (2008). The research and application of medicinal plants Pseudostellaria heterophylla (Miq.) Pax. Res. Pract. Chin. Med. 22 (2), 61-65.

Yu, X., Hu, J. T., Lai, J., Wang, R. Z., Ma, L. L., and Tang, Z. H. (2018). Comparison of the biological characteristics of primary rat macrophages extracted by three methods. Chin. J. Tissue Eng. Res. 22 (24), 3863-3868.

Zeng, L. X., Dong, J. C., Yu, W. Q., Huang, J. H., Liu, B. J., and Feng, X. T. (2010). Baicalin attenuates inflammation by inhibiting NF- $\kappa B$ activation in cigarette smoke induced inflammatory models. Pulm. Pharmacol. Ther. 23 (5), 411-419. doi: 10.1016/j.pupt.2010.05.004

Zhou, Z. R. (2005). Fufangtaizishenzhikeyiqisan were used to treatment of bronchial asthma 2180 examples. J. Med. \&Pharmacy Chin. Minorities 11 (5), 12-13.

Conflict of Interest: The authors declare that the research was conducted in the absence of any commercial or financial relationships that could be construed as a potential conflict of interest.

Copyright $\odot 2020$ Lu, Yang, Lin, Zhao, Jiang, Chen, Liu, Kan, Hu and Pang. This is an open-access article distributed under the terms of the Creative Commons Attribution License (CC BY). The use, distribution or reproduction in other forums is permitted, provided the original author(s) and the copyright owner(s) are credited and that the original publication in this journal is cited, in accordance with accepted academic practice. No use, distribution or reproduction is permitted which does not comply with these terms. 